\title{
ANALISIS KELAYAKAN PENANGKARAN BENIH KELAPA DALAM DI KABUPATEN BANGGAI TAHUN 2010
}

\author{
Heny Ariwijaya \\ Dosen Fakultas Ekonomi Universitas Tompotika Luwuk
}

\begin{abstract}
ABSTRAK
Analisis kelayakan penangkaran benih kelapa dalam di Kabupaten Banggai Tahun 2010. Tujuan dari penelitian ini adalah untuk menganalisis kelayakan usaha penangkaran benih kelapa dalam di Kabupaten Bangga.Metode pengumpulan Data yang digunakan dalam penelitian ini adalah metode dokumentasi dan survey, sedangkan alat analisis yang digunakan dalam penelitian ini adalah metode kelayakan investasi, yakni : NPV, IRR, Net B/C, PP dan sensitivitas. Hasil pembahasan dalam penelitian ini berdasarkan nilai kriteria investasi penangkaran benih kelapa dalam di Kabupaten Banggai Tahun 2010 yaitu : Net Present Value (NPV) sebesar Rp. 42.393.639,76,-, Internal Rate of Return (IRR) sebesar 38.91\%, Net Benefit Cost Ratio (Net B/C) sebesar 1.41 dan Payback Period (PP) selama 3 Tahun, dengan menggunakan alat sensitivitas, maka hasil perhitungan ini kelayakan investasi penangkaran benih kelapa dalam di Kabupaten Banggai Layak di Laksanakan.
\end{abstract}

Kata kunci ; Analisis kelayakan, penangkaran benih, Kelapa dalam

\section{Pendahuluan}

Sasaran utama bisnis tanaman perkebunan adalah pasar luar negeri. Hal ini tidak lepas dari kebijakan pemerintah dalam membangun agribisnis perkebunan. Sasaran pembangunan perkebunan pada tahun 2009 diarahkan untuk mendukung peningkatan pendapatan dan kesejahteraan masyarakat perkebunan melalui peningkatan produksi, produktivitas, nilai tambah, dan daya saing perkebunan (Deptan, 2007).

Benih merupakan unsur yang sangat penting untuk meningkatkan produksi, produktivitas, nilai tambah dan daya saing perkebunan dalam upaya meningkatkan pendapatan dan kesejahteraan petani. Semua orang mengenal kata benih, baik dalam arti sebenarnya maupun kiasan. Keduanya memberikan makna benih itu asal suatu proses dan dalam kaitan waktu, awal suatu kejadian. Menurut perundangan yang berlaku (UU No. 12 tahun 1992 tentang Sistem Budidaya Tanaman dan PP No. 44 tahun 1995 tentang Perbenihan Tanaman) yang dimaksud dengan benih adalah semua bentuk bahan tanaman dari proses generatif berupa biji maupun vegetatif seperti stek, cangkok, umbi dan lain-lain (Sadjad, 1997).

Salah satu komoditas primadona pada subsektor perkebunan adalah kelapa (Cocos nucifera). Kelapa merupakan komoditi penting dan merupakan bagian dari kehidupan masyarakat Indonesia, karena dari daun, buah dan batang dapat dimanfaatkan. Produk tanaman kelapa selain untuk memenuhi kebutuhan masrakat juga sebagai sumber devisa negara melalui ekspor. Selain itu 
komoditi ini dapat menyerap tenaga kerja yang tidak sedikit yaitu sekitar 6,9 juta KK, serta telah berperan penting dalam mendorong pertumbuhan sentra-sentra ekonomi baru di wilayah-wilayah pengembangan (Deptan, 2007)

Areal tanaman kelapa di Indonesia merupakan areal terluas nomor satu di dunia yaitu mencapai $31,92 \%$ dari total luas areal kelapa dunia (Dirjenbun, 2007). Namun demikian apabila ditinjau dari aspek produksi, Indonesia hanya menduduki posisi kedua setelah Philipina. Kondisi ini menunjukkan bahwa produktivitas kelapa Indonesia masih dibawah produktivitas kelapa Philipina. Hal tersebut dikarenakan pada awal pelaksanaan usaha budidaya kelapa, pengusahaannya masih menggunakan varietas-varietas asalan yang bukan berasal dari Blok Penghasil Tinggi (sumber benih unggulan).

Kabupaten Banggai Propinsi Sulawesi Tengah mengembangkan kelapa sebagai salah satu unggulannya. Tanaman kelapa tersebut banyak diusahakan oleh petani di Kabupaten Banggai, karena selain kondisi iklim dan jenis tanahnya yang sesuai, juga tersedianya peluang pasar untuk pengembangan agribisnis, baik usaha pembibitan maupun pengembangan usaha budidaya. Luas areal, produksi dan produktivitas tanaman kelapa di Kabupaten Banggai terdapat pada Tabel 1.

Tabel 1. Luas Areal, Produksi dan Produktivitas Tanaman Kelapa di Kabupaten Banggai, Tahun 2005-2009

\begin{tabular}{|c|c|c|c|c|c|c|c|c|}
\hline \multirow[b]{3}{*}{ No } & \multirow{3}{*}{ Tahun } & \multicolumn{5}{|c|}{ Luas Lahan } & \multirow{3}{*}{$\begin{array}{l}\text { Produksi } \\
\quad \text { (ton) }\end{array}$} & \multirow{3}{*}{$\begin{array}{c}\text { Produktifitas } \\
(\mathrm{kg} / \mathrm{h})\end{array}$} \\
\hline & & \multicolumn{3}{|c|}{ Yang dimanfaatkan $(\mathrm{h})$} & \multirow{2}{*}{$\begin{array}{c}\text { Jumlah } \\
\text { (h) }\end{array}$} & \multirow{2}{*}{$\begin{array}{c}\text { Belum } \\
\text { dimanfaatkan } \\
(\mathrm{h}) \\
\end{array}$} & & \\
\hline & & TBM & $\mathrm{TM}$ & $\mathrm{TT} / \mathrm{TR}$ & & & & \\
\hline 1 & 2005 & 4.313 & 23.330 & 4.061 & 31.704 & 26.371 & 29.657 & 1,27 \\
\hline 2 & 2006 & 3.934 & 24.303 & 1.015 & 29.252 & 20.492 & 32.500 & 1,34 \\
\hline 3 & 2007 & 4.352 & 23.749 & 2.173 & 30.274 & 15.525 & 36.218 & 1,53 \\
\hline 4 & 2008 & 5.593 & 23.322 & 3.771 & 32.686 & 7.929 & 26.366 & 1,13 \\
\hline 5 & 2009 & 6.151 & 22.885 & 2.433 & 31.458 & 11.552 & 24.512 & 1,07 \\
\hline
\end{tabular}

Sumber : Dinas Perkebunan Kabupaten Banggai, 2010

Komoditi kelapa merupakan salah satu komoditas perkebunan andalan Kabupaten Banggai. Produksi tanaman kelapa tersebut tersebar di 13 (tiga belas) kecamatan yaitu Kecamatan Toili, Toili Barat, Batui, Kintom, Luwuk, Luwuk Timur, Masama, Lamala, Balantak, Bualemo, Pagimana, Bunta, dan Nuhon.

Berdasarkan data produksi tersebut diatas, secara umum dapat digambarkan bahwa penurunan angka produksi tersebut dipengaruhi oleh banyaknya jumlah populasi tanaman kelapa yang tergolong usia tua dan tidak produktif lagi.
Untuk menanggulangi hal tersebut diperlukan adanya kegiatan peremajaan/rehabilitasi kelapa rakyat yang tentunya harus dibarengi pula dengan penyediaan bibit yang berkualitas. Ketersediaan bibit yang berkualitas tentunya harus terdapat pula sumber benih kelapa yang sering disebut dengan Blok Penghasil Tinggi kelapa. Selain ketersediaan bibit, diperlukan pula penangkar bibit yang profesional yang menerapkan standar baku teknis penangkaran benih kelapa, sehingga kelapa yang didistribusikan adalah benih 
kelapa yang benar-benar unggul dari segi

\section{Metode Penelitian}

Jenis penelitian ini adalah penelitian deskriptif, yang memberi gambaran tentang fakta-fakta yang diperoleh di lapangan. Pengumpulan data dilakukan dengan metode survey, observasi langsung di lapangan. Data yang dikumpulkan adalah data faktual dan aktual. Data yang terkumpul dari responden terpilih, ditabulasi, diedit dan dianalisis serta dijelaskan secara deskriptif.

Penelitian ini dilaksanakan di penangkaran kelapa di Wilayah Kabupaten Banggai, yang terdapat di Desa Uwelolu Kecamatan Toili Barat, Desa Rusa Kencana Kecamatan Toili, Kelurahan Lamo Kecamatan Batui, Desa Babang Buyangge Kecamatan Kintom, Desa Tangkiang Kecamatan Kintom dan Desa Hunduhon Kecamatan Luwuk Timur. Pemilihan tempat penelitian ini dilakukan dengan sengaja (purposive), dengan pertimbangan bahwa penangkaran benih kelapa merupakan lembaga usaha perbenihan (Penangkar) kelapa dengan produksi yang variatif serta wilayah distribusi tersebar di seluruh kecamatan di Wilayah Kabupaten Banggai.

\section{NPV (Net Present Value)}

Alasan rasional untuk metode $\mathrm{Net}$ Present Value $(N P V)$ yaitu sangat jelas. NPV sebesar nol menyiratkan bahwa arus kas proyek sudah mencukupi untuk membayar kembali modal yang diinvestasikan dan memberikan tingkat pengembalian yang diperlukan atas modal tersebut. Jika proyek memiliki NPV positif, maka proyek tersebut menghasilkan lebih banyak kas dari yang dibutuhkan untuk menutup utang dan teknis.

memberikan pengembalian yang diperlukan kepada pemegang saham perusahaan.

$$
\begin{array}{cl}
\text { NPV }= & \sum_{\mathbf{t}=0} \mathbf{t}=\mathbf{n} \\
\text { Dimana }-\boldsymbol{C t})(\boldsymbol{D F}) \\
\mathrm{NPV}= & \text { Net Present Value; } \\
\mathrm{Bt} & =\text { benefit pada tahun ke-t; } \\
\mathrm{Ct} & =\text { cost pada tahun ke-t; } \\
\mathrm{DF} & =\text { discount factor; } \\
\mathrm{I} & =\text { tingkat bunga yang } \\
\text { berlaku; } & \\
\mathrm{n}= & \text { lamanya waktu proyek. }
\end{array}
$$

\section{IRR (Internal Rate of Return)}

Internal Rate of Return (IRR) merupakan salah satu metode untuk mengukur tingkat investasi, dalam hal ini adalah tingkat dimana seluruh net cash flow setelah dikalikan discount factor atau telah di present valuekan, nilainya sama dengan nilai investment (biaya investasi) rumus yang digunakan :

$$
I R R=i_{1}+\frac{N P V_{1}}{N P V_{1}-N P V_{2}} \quad\left(i_{2}-i_{1}\right)
$$

Keterangan :

IRR > Bunga modal, layak untuk diusahakan dan menguntungkan

IRR < Bunga modal, tidak layak untuk diusahakan dan tidak menguntungkan

$\mathrm{I}_{1}$ = tingkat bunga (DF) pertama diperoleh dari NPV 1

$\mathrm{I}_{2}$ = tingkat bunga (DF) pertama diperoleh dari NPV 2

$\mathrm{NPV}_{1}=\mathrm{NPV}$ pada discount rate $\mathrm{i}_{1}$

$\mathrm{NPV}_{2}=\mathrm{NPV}$ pada discount rate $\mathrm{i}_{2}$ 


\section{Net B/C (Net Benefit Cost Ratio)}

Net Benefit Cost Ratio (Net B/C) merupakan perbandingan antara jumlah NPV positif dan NPV negatif. Net B/C menunjukkan gambaran beberapa kali lipat benefit akan diperoleh dari cost yang dikeluarkan. Dimana benefit tiap tahun dikurangkan dengan cost untuk mengetahui benefit netto yang positif dan negatif, kemudian jumlah present value positif dibandingkan dengan present value negatif rumusnya dapat dijabarkan sebagai berikut :

$$
\text { Net } \mathrm{B} / \mathrm{C}=\frac{\sum_{\mathrm{t}=\mathbf{0}}^{\mathrm{t}=\mathrm{n}} N P V_{1}}{\sum_{\mathrm{t}=\mathbf{n}} N P V_{2}}
$$

Keterangan :

$$
\begin{array}{ll}
\mathrm{B} & =\text { Manfaat atau Benefit } \\
\mathrm{C} & =\text { Biaya atau Cost } \\
\mathrm{NPV}_{1} & =\text { net present value positif } \\
\mathrm{NPV}_{2} & =\text { net present value negatif } \\
\mathrm{n} & =\text { lamanya periode waktu }
\end{array}
$$

\section{PP (Payback Period)}

Payback Period (PP) merupakan suatu metode yang diperlukan untuk menutup kembali pengeluaran investasi dengan menggunakan aliran kas.

Dengan kata lain Payback Period (PP) merupakan rasio antara initial cash investmen dan cash flow yang dihasilkannya merupakan satuan waktu. Selanjutnya nilai rasio ini dibandingkan dengan maksimum payback period yang dapat diterima, rumus yang digunakan :

$$
\text { Payback Period }=\frac{\text { Pengeluaran investasi }}{\text { Besarnya aliran kas masuk }}
$$

\section{Analisis Sensitifitas}

Secara umum proyek atau usaha cenderung lebih sensitif terhadap kenaikan biaya akibat adanya perubahan kebijakan. Biasanya perubahan proporsional yang ditetapkan dalam biaya pokok dan perincian pengembalian akan mempunyai pengaruh lebih dari yang telah ditetapkan terhadap ukuran-ukuran kemanfaatan proyek yang dihitung, oleh karena itu dilakukan analisis sensitifitas. Dalam hal ini untuk penangkaran benih kelapa dalam dilakukan perubahan terhadap kenaikan harga bahan baku sebesar $24 \%$.

\section{Deskriptif}

Industri benih yang terwujud dalam penangkaran benih kelapa dalam dapat bersaing mengembangkan produknya jika mempunyai keunggulan dibandingkan dengan perusahaan lainnya. Keunggulan produk hanya bisa diperoleh jika perusahaan benih dapat menghasilkan benih bermutu yang diminati petani.

Sadjad (1997) mengemukakan bahwa teknologi dalam industri benih diawali dengan teknologi sederhana yang ditarafkan sebagai industri benih tingkat I. Taraf industri benih tingkat II merupakan industri yang menggunakan mesin-mesin pembersih. Taraf industri benih tingkat III apabila industri benih ini melaksanakan pemilahan benih yang sudah bersih. Industri benih tingkat IV disamping memproses produksinya sebagaimana pada industri tingkat III, industri ini selalu berhubungan dengan kegiatan lembaga litbang. Industri benih tingkat $\mathrm{V}$ memiliki kemampuan memproduksi benih hasil litbang sendiri. 


\section{Hasil dan Pembahasan Investasi}

Investasi merupakan variabel ekonomi sebagai penghubung antara kondisi saat ini dengan masa yang akan datang, sehingga dalam hal ini peranan suku bunga sangat penting. Kesamaan dari semua investasi ini adalah harapan memperoleh keuntungan di kemudian hari.

Tabel 2. Investasi Awal Rata-rata Penangkaran Benih Kelapa Dalam

\begin{tabular}{|c|r|r|}
\hline \hline No & Jenis Investasi & \multicolumn{1}{c|}{ Nilai } \\
\hline \hline 1. & Lahan Usaha & 983.333 .33 \\
\hline 2. & Mesin dan Peralatan Usaha & $60.956 .666,67$ \\
\hline 3. & Inventarisasi Administrasi & 4.966 .666 .67 \\
\hline \hline \multicolumn{1}{|c|}{ Total } & $\mathbf{6 6 . 9 0 6 . 6 6 6 , 6 7}$ \\
\hline \hline
\end{tabular}

Dalam penelitian ini 6 penangkaran benih kelapa dalam yang menjadi responden masing-masing menggunakan modal sendiri. Keuntungan menggunakan modal sendiri untuk membiayai suatu usaha adalah tidak adanya beban biaya bunga seperti modal pinjaman. Perusahaan hanya berkewajiban membayar dividen. Pembayaran dividen dilakukan jika perusahaan memperoleh keuntungan dan besarnya dividen tergantung dari keuntungan perusahaan. Kemudian tidak adanya kewajiban untuk mengembalikan modal yang telah digunakan. Kerugian menggunakan modal sendiri yaitu jumlahnya sangat terbatas dan relatif sulit untuk memperolehnya.

\section{Biaya}

Biaya adalah semua dana atau korbanan yang dikeluarkan dalam suatu usaha, yang meliputi biaya variabel dan biaya tetap dan dinyatakan dalam rupiah (Rp).

\section{Biaya Variabel}

Biaya variabel adalah biaya yang besarnya tergantung pada produksi yang dihasilkan. Semakin banyak produk yang dihasilkan maka semakin besar biaya variabel yang dikeluarkan. Dalam penangkaran benih kelapa dalam di Kabupaten Banggai biaya variabel meliputi ; pembelian benih (biji), pupuk, pestisida, BBM, selang, naungan, sisa benih (bibit) yang tidak terjual, transportasi dan tenaga kerja.

\section{Biaya Tetap}

Biaya tetap adalah biaya yang besarnya tidak tergantung pada banyak sedikitnya produk yang dihasilkan. Biaya tetap meliputi ; biaya pajak, sewa lahan dan penyusutan peralatan. 


\begin{tabular}{|c|c|c|c|}
\hline \multicolumn{4}{|c|}{ Kelapa Dalam Tahun 2010-2014 } \\
\hline Tahun & Biaya Variabel & Piaya Tetap & Total Biaya \\
\hline & (Rp) & (Rp) & (Rp) \\
\hline 2010 & $58.116 .528,33$ & $3.689 .916,67$ & $61.806 .445,00$ \\
\hline 2011 & $62.270 .412,24$ & $3.689 .916,67$ & $65.960 .328,91$ \\
\hline 2012 & 72.307.917,01 & $3.689 .916,67$ & $75.997 .833,67$ \\
\hline 2013 & $80.465 .443,76$ & $3.689 .916,67$ & $84.155 .360,43$ \\
\hline 2014 & $87.491 .911,67$ & $3.689 .916,67$ & $90.181 .828,34$ \\
\hline
\end{tabular}

Tabel 3 menunjukan bahwa terjadi peningkatan biaya variabel setiap tahunnya yang diakibatkan oleh kenaikan sejumlah biaya-biaya produksi meliputi biaya benih, pupuk, pestisida, BBM, selang, naungan, transportasi dan tenaga kerja. Sedangkan untuk biaya tetap tidak mengalami kenaikan, sebab biaya tetap meliputi biaya pajak, penyusutan peralatan, dan sewa lahan. Untuk biaya penyusutan terjadi kenaikan setiap 5 tahun, karena pembelian peralatan untuk penangkaran benih kelapa dalam rata-rata memiliki umur ekonomis sekitar 5 tahun. Begitu pula dengan pajak dan sewa lahan, tidak mengalami kenaikan setiap tahunnya, sehingga tidak adanya perubahan besarnya biaya tetap.

\section{Produksi dan Penerimaan}

Produksi dalam suatu usaha merupakan hal penting yang harus diperhatikan, sebab hal ini akan menggambarkan apakah proses atau kegiatan operasional dalam sebuah usaha sudah maksimal atau belum. Produksi dalam penangkaran benih kelapa dalam di Kabupaten Banggai yang akan memberikan gambaran berapa besar penerimaan yang akan diperoleh. Produksi kelapa dalam sangat dipengaruhi oleh jumlah permintaan konsumen terhadap benih kelapa dalam. Produksi penangkaran benih kelapa dalam di Kabupaten Banggai adalah 100.680 benih dengan rata-rata produksi 16.780 benih, penjualan benih 97.750 benih dengan rata-rata penjualan 16.292.

Penerimaan merupakan jumlah uang yang diterima, yang diperoleh dari hasil produksi dikali dengan harga jual produk yang dinyatakan dalam rupiah. Penerimaan sangat dipengaruhi oleh jumlah produksi yang dihasilkan. Penerimaan rata-rata penangkaran benih kelapa dalam di Kabupaten Banggai sejumlah Rp. 81.458.333,33

\section{Pendapatan}

Pendapatan diperoleh dari selisih antara penerimaan dengan total biaya yang dikeluarkan selama umur usaha yang direncanakan lima tahun. Usaha akan memperoleh laba apabila hasil selisih antara penerimaan dengan biaya bernilai positif, sebaliknya jika hasilnya negatif maka suatu usaha dinyatakan mengalami kerugian.

\section{Laba Sebelum Pajak Usaha}

Laba sebelum pajak disebut juga pendapatan usaha, yang merupakan hasil yang diperoleh dari penerimaan bersih dikurangi total biaya dalam satu periode tertentu. Laba sebelum pajak penangkaran 
benih kelapa dalam di Kabupaten Banggai sejumlah Rp. 29.390.693,47, artinya bahwa setelah penerimaan dikurangi biaya variabel dan biaya tetap sejumlah Rp. 52.067.639,86, usaha tersebut menguntungkan dan layak dari aspek finansial.

\section{Laba Bersih}

Laba bersih merupakan keuntungan usaha yang hasilnya diperoleh dari penerimaan usaha dikurangi total biaya yang telah ditambahkan dengan pajak usaha setiap tahunnya. Laba setelah pajak penangkaran benih kelapa dalam di Kabupaten Banggai sejumlah Rp. 24.982.089,45, artinya bahwa penerimaan dari hasil penjualan benih kelapa dalam sejumlah Rp. 81.458.333,33 setelah dikurangi dengan total biaya sejumlah 52.067.639,47 dan ditambahkan dengan pajak sejumlah Rp. 4.408.604,02, usaha tersebut menguntungkan dan layak dari aspek finansial.

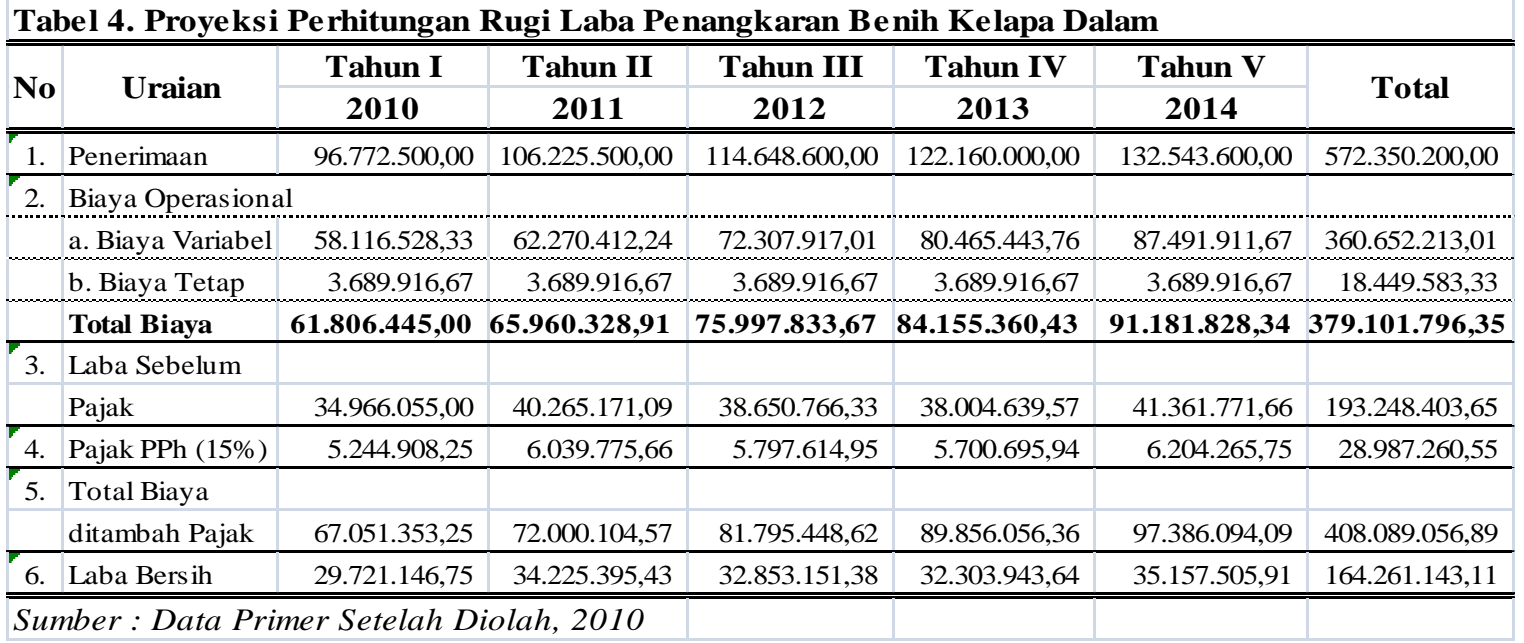

Tabel 4 menunjukan penerimaan bersih rata-rata diperoleh selama lima tahun dari penangkaran benih kelapa dalam sejumlah Rp. 572.350.200,00,- dan menghasilkan laba bersih sejumlah Rp. 164.261.143,11,-, hal tersebut menandakan bahwa proyeksi permintaan benih kelapa dalam pada lima tahun mendatang sangat tinggi yang mengakibatkan peningkatan produksi dan penerimaan.

\section{Kelayakan Investasi}

Net Present Value (NPV) Net Present Value merupakan salah satu teknik analisis yang digunakan untuk mempertimbangkan nilai waktu dari uang. Kriteria ini digunakan untuk menghitung selisih nilai sekarang investasi penangkaran benih kelapa dalam dengan nilai sekarang penerimaan kas bersih dimasa yang akan datang. Untuk menghitung nilai sekarang investasi harus diperhitungkan tingkat bunga yang dianggap relevan atau bunga pinjaman yang berlaku sekarang. Berdasarkan survei beberapa lembaga keuangan yang telah dilakukan dapat diambil tingkat bunga bank yang digunakan adalah sebesar $15 \%$. Apabila nilai sekarang aliran kas bersih dimasa yang akan datang lebih besar dari pada nilai sekarang 
investasi, maka usaha tersebut dinyatakan

diusahakan.

layak atau menguntungkan untuk

Tabel 5. Perhitungan NPV Selama 5 Tahun pada Penangkaran Benih Kelapa Dalam di Kabupaten Banggai

\begin{tabular}{|c|r|c|r|}
\hline \hline Tahun & Aliran Kas Mas uk & DF (15\%) & \multicolumn{1}{c|}{ Nilai Sekarang } \\
\hline \hline 0 & $(66.906 .666,67)$ & 1 & $(66.906 .666,67)$ \\
\hline 1 & $29.721 .146 ., 75$ & 0,870 & $25.857 .397,67$ \\
\hline 2 & $34.225 .395,43$ & 0,756 & $25.874 .398,95$ \\
\hline 3 & $32.853 .151,38$ & 0,658 & $21.617 .373,61$ \\
\hline 4 & $32.303 .943,64$ & 0,572 & $18.477 .855,76$ \\
\hline 5 & $35.157 .505,91$ & 0,497 & $17.473 .280,44$ \\
\hline \hline \multicolumn{3}{|c|}{ Nilai Bersih Sekarang } \\
\hline \hline
\end{tabular}

Sumber: Data Primer Setelah Diolah, 2010

Nilai $N P V$ jumlah aliran kas masuk yang diperoleh pada penangkaran benih kelapa dalam di Kabupaten Banggai yang didiskontokan dengan tingkat bunga $15 \%$ diperoleh sebesar Rp. 42.393.639,76,nilai ini menunjukan bahwa $N P V$ bernilai positif, bahwa penangkaran benih kelapa dalam di Kabupaten Banggai secara finansial layak diusahakan. Nilai $N P V>$ 0 berarti bahwa penanaman investasi pada penangkaran benih kelapa dalam di Kabupaten Banggai sebesar Rp. 66.906.666,67,- akan memberikan keuntungan sebesar

$\mathrm{Rp}$.

42.393.639,76,- selama lima tahun.

\section{Internal Rate of Return (IRR)}

Internal Rate of Return (IRR) adalah suatu kriteria investasi untuk mengetahui persentase keuntungan pada setiap periode yang direncanakan. Pada dasarnya IRR menunjukan discount factor (DF) dimana NPV $=0$, apabila diperoleh nilai IRR lebih besar dari pada bunga bank yang berlaku, maka proyek atau usaha tersebut menguntungkan atau layak untuk dijalankan.

Tabel 6. Perhitungan Internal Rate of Return (IRR) pada Penangkaran Benih Kelapa Dalam di Kabupaten Banggai

\begin{tabular}{|c|c|c|c|c|c|c|c|}
\hline \multirow{2}{*}{ Tahun } & Profit & DF & \multirow{2}{*}{ NPV1 } & \multirow{2}{*}{$\begin{array}{c}\text { DF } \\
(38 \%)\end{array}$} & \multirow{2}{*}{ NPV } & \multirow{2}{*}{$\begin{array}{c}\text { DF } \\
(39 \%) \\
\end{array}$} & \multirow{2}{*}{ NPV2 } \\
\hline & (Rp) & $(15 \%)$ & & & & & \\
\hline 0 & $(66.906 .666,67)$ & 1 & $(66.906 .666,67)$ & 1 & $(66.906 .666,67)$ & 1 & $(66.906 .666,67)$ \\
\hline 1 & $29.721 .146,75$ & 0,870 & $25.857 .397,67$ & 0,725 & $21.535 .942,94$ & 0,719 & 21.381.392,97 \\
\hline 2 & $34.225 .395,43$ & 0,756 & $25.874 .398,95$ & 0,525 & $17.971 .755,14$ & 0,518 & $17.711 .642,14$ \\
\hline 3 & $32.853 .151,38$ & 0,658 & $21.617 .373,61$ & 0,381 & $12.500 .624,10$ & 0,372 & $12.231 .228,26$ \\
\hline 4 & $32.303 .943,64$ & 0,572 & $18.477 .855,76$ & 0,276 & $8.906 .197,26$ & 0,268 & $8.650 .996,11$ \\
\hline \multirow[t]{2}{*}{5} & 35.157.505,91 & 0,497 & $17.473 .280,44$ & 0,200 & 7.024.469,68 & 0,193 & $6.774 .851,39$ \\
\hline & Total & & 42.393.639,76 & & $1.032 .322,45$ & & $(156.555,81)$ \\
\hline
\end{tabular}

Sumber : Data Primer Setelah Diolah, 2010

Nilai IRR menunjukan nilai NPV positif terakhir berada pada DF $38 \%$, sedangkan

DF 39\% sudah menunjukan nilai NPV yang negatif. Perhitungan IRR yang 
menunjukan nilai positif pada DF $38 \%$ memberikan gambaran bahwa penangkaran benih kelapa dalam di Kabupaten Banggai mampu menghasilkan keuntungan diatas bunga pinjaman (DF15\% s/d DF 38\%).

Pada tingkat bunga $15 \%$ menghasilkan NPV Rp. 42.393.639,76,- sedangkan tingkat bunga terakhir yang bernilai positif pada DF 38\% menghasilkan NPV Rp. 1.032.322,45,- Pada tingkat bunga $39 \%$ menghasilkan NPV bernilai negatif $(156.555,81)$ atau $<0$ atau dengan kata lain usaha telah mengalami kerugian. Jadi perhitungan NPV $=0$ terletak antara interet rate $38 \%$ dan $39 \%$, setelah diperoleh NPV positif dan NPV negatif, maka nilai IRR dapat dihitung dengan rumus sebagai berikut :

$$
\mathrm{IRR}=i_{1}+\frac{\mathrm{NPV}_{1}}{\mathrm{NPV}_{1}-\mathrm{NPV}_{2}} \times\left(i_{2}-i_{1}\right)
$$

$\mathrm{IRR}=15 \%+$ $\mathrm{x}(39 \%-15 \%)$

$42.393 .639,76-(-156.555,81)$

$$
\operatorname{IRR}=15 \%+\frac{42.393 .639,76}{42.550 .195,57} \quad x(24 \%)
$$

$\mathrm{IRR}=\mathbf{3 8 , 9 1 \%}$

Nilai $I R R$ 38,91\% menunjukan nilai $I R R$ $>$ tingkat bunga bank yang berlaku, berarti penangkaran benih kelapa dalam di Kabupaten Banggai layak untuk diusahakan. Penangkaran benih kelapa dalam di Kabupaten Banggai dapat beroperasi sampai batas bunga pinjaman $38 \%$ pertahun.

\section{Net Benefit Cost Ratio (Net B/C)}

Net Benefit Cost Ratio (Net B/C) adalah perbandingan antara jumlah NPV positif dengan jumlah NPV negatif.

\begin{tabular}{|c|c|c|c|c|c|c|}
\hline Tahun & $\begin{array}{c}\text { Benefit } \\
\text { (Rp) }\end{array}$ & $\begin{array}{l}\text { Cost } \\
\text { (Rp) } \\
\end{array}$ & $\begin{array}{l}\text { Profit } \\
(\text { Rp) }\end{array}$ & $\begin{array}{c}\text { DF } \\
(15 \%) \\
\end{array}$ & $\begin{array}{c}\text { Net Benefit } \\
\text { (Rp) }\end{array}$ & $\begin{array}{c}\text { Net Cost } \\
\text { (Rp) }\end{array}$ \\
\hline 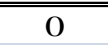 & & & $(66.906 .666,67)$ & 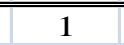 & & \\
\hline 1 & $96.772 .500,00$ & $67.051 .353,25$ & $29.721 .146,75$ & 0,870 & $84.192 .075,00$ & $58.334 .677,33$ \\
\hline 2 & $106.225 .500,00$ & $72.000 .104,57$ & $34.225 .395,43$ & 0,756 & $80.306 .478,00$ & $54.432 .079,05$ \\
\hline 3 & $114.648 .600,00$ & $81.795 .448,62$ & $32.853 .151,38$ & 0,658 & $75.438 .778,80$ & $53.821 .405,19$ \\
\hline 4 & $122.160 .000,00$ & $89.856 .056,36$ & $32.303 .943,64$ & 0,572 & $69.875 .520,00$ & $51.397 .664,24$ \\
\hline 5 & $132.543 .600,00$ & $97.386 .094,09$ & $35.157 .505,91$ & 0,497 & $65.874 .169,20$ & $48.400 .888,76$ \\
\hline & \multicolumn{2}{|c|}{ Total } & $97.354 .476,44$ & & 375.687.021,00 & $266.386 .714,58$ \\
\hline
\end{tabular}

Tabel 7. Analisis Net B/C Ratio Penangkaran Benih Kelapa Dalam di Kabupaten Banggai

Sumber : Data Primer Setelah Diolah, 2010

Tabel 7 menunjukan nilai NPV positif dan NPV negatif, dimana nilainya dapat digunakan untuk menghitung nilai $\mathrm{Net}$ Benefit Cost Ratio (Net B/C) dengan menggunakan rumus sebagai berikut :

$$
\sum_{\mathrm{t}=0}^{\mathrm{t}=\mathrm{n}} \mathrm{NPV}_{1}
$$

Net $B / C=$

$$
\sum_{\mathrm{t}=0}^{\mathrm{t}=\mathrm{n}} \mathrm{NPV}_{2}
$$

$$
\text { Net } B / C=\frac{375.687 .021,00}{266.386 .714,58}
$$

$\operatorname{Net}(B / C)=1.41$ 
Hasil perhitungan diperoleh nilai $\mathrm{Net}$ $(B / C)$ sebesar 1.41, hal ini mengindikasikan bahwa penangkaran benih kelapa dalam di Kabupaten Banggai layak untuk dijalankan. Nilai $\mathrm{Net}$ $(B / C)=1,42$ artinya bahwa dengan menginvestasikan uang sebesar Rp. 1,akan memperoleh keuntungan sebesar Rp. 1,42 ,-

\section{Payback Period (PP)}

Perhitungan Payback Period dapat dilihat dari perhitungan kas bersih yang diperoleh setiap tahun, nilai kas bersih diperoleh dari penerimaan usaha yang dikurangi total biaya setelah ditambah pajak. Perhitungan Payback Period penangkaran benih kelapa dalam di
Kabupaten Banggai bertujuan untuk melihat berapa lama waktu yang digunakan untuk dapat mengembalikan dana pinjaman atau modal dalam kegiatan investasi yang dijalankan.

Payback Period penangkaran benih kelapa dalam di Kabupaten Banggai dapat dilihat dari cash inflow yang diperoleh setiap tahun. Nilai kas bersih pada tahun pertama dan tahun kedua

sebesar Rp. 63.946.542,18,- belum menutupi seluruh investasi awal sebesar Rp. 66.906.666,67,- namun pada tahun ketiga nilai kas bersih sudah melebihi investasi awal yaitu sebesar Rp. 96.799.693,56,--

\section{Tabel 8. Perhitungan Payback Period Penangkaran Benih Kelapa Dalam di Kabupaten Banggai}

\begin{tabular}{l|r}
\hline \hline \multicolumn{1}{c|}{ Uraian } & \multicolumn{1}{c}{ Nilai } \\
\hline \hline Investasi & $66.906 .666,67$ \\
\hline Kas Masuk Tahun I & $29.721 .146,75$ \\
\hline Sisa & $37.185 .519,92$ \\
\hline Kas Masuk Tahun II & $34.225 .395,43$ \\
\hline Sisa & $2.960 .124,49$ \\
\hline Kas Masuk Tahun III & $32.853 .151,38$ \\
\hline \hline
\end{tabular}

Sumber : Data Primer Setelah Diolah, 2010

Payback Period $=\quad \frac{2.960 .124,49}{32.853 .151,38} \times 12=1,081$

Tabel 9. Analisis Sensitifitas pada Penangkaran Benih Kelapa Dalam di Kabupaten Banggai

\begin{tabular}{|c|l|c|}
\hline \hline No & \multicolumn{1}{|c|}{ Kriteria Investasi } & Nilai \\
\hline \hline 1 & Net Present Value (NPV) & Rp. 14.112.591,24 \\
\hline 2 & Internal Rate of Return (IRR) & $23,74 \%$ \\
\hline 3 & Net Benefit Cost Ratio (Net B/C) & 1,27 \\
\hline 4 & Payback Period (PP) & 3 Tahun \\
\hline \hline
\end{tabular}

Sumber : Data Primer Setelah Diolah, 2010 
Hasil perhitungan sisa investasi tahun kedua dibagi dengan aliran kas masuk tahun ketiga dikali dengan 12 bulan dalam setahun diperoleh 1,081 bulan, yang berarti masa pemulihan modal lebih singkat waktunya dari payback period yang telah direncanakan. Payback period 3 tahun dikarenakan periode penerimaan penangkaran benih kelapa dalam dihitung

\section{Analisis Sensitifitas}

Dalam sebuah usaha yang menggunakan jangka waktu relatif panjang terdapat beberapa kemungkinan yang terjadi di luar dugaan dan prediksi, salah satunya kenaikan harga bahan baku. Pada benih kelapa dalam di Kabupaten Banggai diasumsikan terjadi perubahan biaya variabel seperti harga benih, pupuk dan pestisida naik sebesar $24 \%$. Kenaikan biaya variabel sebesar $24 \%$ merupakan selisih antara tingkat bunga bank yang berlaku (DF 15\%) dengan tingkat bunga bank (DF 39\%) yang bernilai negatif.

Hasil analisis sensitifitas dengan kenaikan biaya bahan baku sebesar $24 \%$ diperoleh nilai NPV sebesar Rp. 14.112.591,24,-, IRR sebesar 23.74\%, Net B/C sebesar 1.27 dan PP selama 3 Tahun, artinya hasil ini menunjukan bahwa dengan kenaikan biaya variabel $24 \%$ penangkaran benih kelapa dalam di Kabupaten Banggai layak untuk diusahakan. Perubahan kenaikan biaya variabel > 24\% diindikasikan penangkaran benih kelapa dalam di Kabupaten Banggai akan mengalami kerugian atau dinyatakan tidak layak.

\section{Deskriptif}

Industri benih merupakan salah satu contoh agroindustri. Keberadaannya akan serasi jika ditempatkan dalam sistem agribisnis. Dalam sistem ini benih tidak maka diketahui payback period yaitu 2 tahun 1 bulan. Jadi payback period penangkaran benih kelapa dalam di Kabupaten Banggai adalah 3 tahun, dalam satuan tahun. Dengan demikian penangkaran benih kelapa dalam di Kabupaten Banggai dapat dinyatakan layak.

lagi di produksi tanpa pandangan komersial. Benih merupakan salah satu unsur di bagian hulu untuk memproduksi bahan olah yang akan di proses dan di distribusikan di bagian hilir. Dari sudut pandang mikro, agribisnis merupakan sistem yang holistik yang mencakup seluruh kegiatan hulu sampai hilir, dari proses produksi di subsistem hulu, pemrosesan produk di subsistem tengah serta tataniaga di subsistem hilir, yang prosesnya saling terkait secara menyeluruh.

Dalam sistem agribisnis ini, produk pertanian dengan teknologi sederhana maupun canggih diproses menjadi produk yang layak untuk dipasarkan.

Berdasarkan hasil penelitian pada penangkaran benih kelapa dalam di Kabupaten Banggai berada pada taraf industri benih tingkat III, dimana pada taraf industri ini penangkar benih telah melaksanakan pengambilan benih dari Blok Penghasil Tinggi (BPT) Kelapa, seleksi benih di BPT, penyayatan benih, pendederan benih, penyiraman, pemupukan, transplanting, pengendalian hama dan penyakit, seleksi benih pada blok transplanting, sertifikasi, dan distribusi. Selain perlakuan penerapan perlakuan teknis tersebut, penangkaran benih pada taraf industri tingkat III ini juga telah menggunakan tenaga kerja tetap dan mesin pembersih dalam proses produksi. Rangkain proses produksi 
tersebut menghasilkan benih yang seragam dari segi fisik, memiliki keunggulan dan teridentifikasi.

Dari penelitian yang dilaksanakan bahwa untuk mencapai pada taraf industri benih tingkat IV masih sangat sulit dilakukan oleh penangkaran benih kelapa dalam di Kabupaten Banggai, dikarenakan pada taraf industri ini benih yang dihasilkan adalah benih yang telah mengakomodasi produk bioteknologi. Taraf industri benih yang menghasilkan benih bioteknologi (somatic) harus memiliki fasilitas laboratorium dan industri benih tingkat $\mathrm{V}$ ini belum dimiliki oleh penangkar benih kelapa dalam di Kabupaten Banggai.

\section{KESIMPULAN DAN SARAN Kesimpulan}

Dari hasil pembahasan, menunjukan nilai perhitungan dengan menggunakan kriteria investasi, mengindikasikan bahwa penangkaran benih kelapa dalam memungkinkan layak untuk dijalankan. Nilai kriteria investasi penangkaran benih kelapa dalam berdasarkan nilai kriteria investasi penangkaran benih kelapa dalam di Kabupaten Banggai yaitu : Net Present Value (NPV) sebesar Rp. 42.393.639,76,-, Internal Rate of Return (IRR) sebesar $38.91 \%$, Net Benefit Cost Ratio (Net B/C) sebesar 1.41 dan Payback Period (PP) selama 3 Tahun.

Saran

kelapa dalam di Kabupaten Banggai tetap dijalankan karena secara finansial penangkaran benih kelapa dalam ini layak untuk dijalankan, dan diharapkan kepada pemerintah yang berwenang dalam bidang ini dapat memberikan perhatian khusus pada pembinaan pola kemitraan dan kerjasama dengan Balai sumber daya manusia yang ahli dalam teknis kultur jaringan.

Pencapaian industri benih menuju taraf industri benih tingat $\mathrm{V}$ lebih sulit dibanding taraf industri benih tingkat IV, dikarenakan harus memiliki lembaga penelitian dan pengembangan internal untuk menghasilkan benih sintetik, dimana benih jenis ini memiliki keunggulan yaitu benih dapat diisi dengan nutrisi, mikroorganisme, dan pestisida yang berguna untuk mendorong serta melindungi pertumbuhan tanaman. Standarisasi yang dicirikan oleh taraf

Setelah dilakukan analisis sensitifitas dengan menaikan harga biaya variabel sebesar $24 \%$ menunjukan bahwa penangkaran benih kelapa dalam di Kabupaten Banggai layak untuk dijalankan. Berdasarkan nilai kriteria investasi penangkaran benih kelapa dalam di Kabupaten Banggai setelah dilakukan analisis sensitifitas adalah : Net Present Value (NPV) sebesar Rp. 14.112.591,24,-, Internal Rate of Return (IRR) sebesar $23.74 \%$, Net Benefit Cost Ratio (Net B/C) sebesar 1.27 dan Payback Period (PP) selama 3 Tahun.

Dengan melihat hasil kriteria investasi, hendaknya penangkaran benih Penelitian Kelapa Mapanget Sulawesi Utara untuk menghasilkan benih unggul maupun benih bina.

Bagi para peneliti yang berminat melakukan penelitian dalam bidang yang sama, diharapkan dapat melanjutkan pengkajian kelayakan finansial ini pada beberapa badan usaha lain yang sejenis, 
baik dengan menggunakan metode analisis/kriteria yang sama maupun

\section{DAFTAR PUSTAKA}

Allorerung, D., 2002. Petunjuk Teknis Budidaya Tanaman Kelapa (Cocos nucifera). Balai Penelitian Tanaman Kelapa dan Palma Lain, Manado.

Angipora, M., 2002. Dasar-dasar Pemasaran. PT. Raja Grafindo Persada, Jakarta.

Bappenas, 2007. Sistim Informasi Manajemen Pembangunan di Perdesaan.

Daniel, M., 2002. Pengantar Ekonomi Pertanian. PT. Bumi Aksara, Jakarta.

Deptan, 2006. Pedoman Teknis Budidaya Tanaman Kelapa/GAP. Deptan, Jakarta.

Deptan, 2007. Prospek dan Arah Pengembangan Agribisnis Kelapa. Deptan, Jakarta.

Deptan, 2007. Rencana Strategis. Departemen Pertanian RI, Jakarta

Deptan, 2007. Road Map Kelapa (Cocos nucifera). Dirjenbun, Jakarta.

Djamin, Z., 1984. Perencanaan dan Analisa Proyek. Fakultas Ekonomi Universitas Indonesia, Jakarta.

Djoehana, S., 1985. Bertanam Kelapa. Kanisius, Jakarta.

Gittinger, J.P. dan Adler, H.A., 1993. Evaluasi Proyek. Rineka Cipta, Jakarta.

Haming, M dan Basalamah, S., 2003. Study Kelayakan Investasi Proyek dan Bisnis. Ppm. Jakarta.

Harmaizar, Z., 2008. Menggali Potensi Wirausaha. CV. Dian Anugerah Prakasa, Bekasi. dengan metode analisis/kriteria yang berbeda.

http://warintek.bantul.go.id tanggal 19 Oktober 2010.

Budiarti, T., 2005. Peranan Benih Dalam Menunjang Pertanian Sebagai Sebagai Suatu Sistem Holistik. Prosiding Seminar Nasional Perbenihan, Palu, 13-14 Agustus 2005. Kerja Sama UNTAD dengan Forum Perbenihan Sulteng, Badan Penelitian dan Pengembangan Prov. Sulteng, dan Dinas Pertanian dan Peternakan Kab. Donggala. p. 76-88.

Heidjrahcman R, Irawan dan Sukanto R., 1982. Pengantar Ekonomi Perusahaan Buku 2. BPFEYogyakarta.

Husnan, S dan Suwarsono., 1999. Studi Kelayakan Proyek. UPP AMP YKPN. Yogyakarta.

Ibrahim, Y., 2003. Studi Kelayakan Bisnis. Rineka Cipta, Jakarta.

Kaat, H., 1995. Pertumbuhan dan Produksi Kelapa Pada Berbagai Tingkat Umur. Buletin Balitka 24 : 30-37.

Kadarsam, H. W, 1992. Keuangan Pertanian dan Pembiayaan Perusahaan Agribisnis. Gramedia Pustaka Utama, Jakarta.

Kasmir dan Jakfar, 2004. Study Kelayakan Bisnis. Prenada Media, Jakarta.

Lay, A., 1995. Teknologi dan Manajemen Usaha Industri Kelapa Terpadu PT. Sari Segar Husada di Lampung. Buletin Balitka 24 : 38-50.

Mubyarto, 1994. Pengantar Ekonomi Pertanian. LP3ES, Jakarta. 
Munawir, S., 2004. Analisa Laporan Keuangan. Liberty, Yogyakarta.

Murdifin, H. dan Salim, B., 2003. Studi Kelayakan Investasi Proyek dan Bisnis. PPM, Jakarta.

Murti dan John, 1995. Pengantar Bisnis (Dasar-dasar Ekonomi Perusahaan), Edisi IV, Liberty, Yogyakarta.

Pudjosumarto, M., 1998. Evaluasi Proyek. Liberty, Yogyakarta.

Purba, R., 1997. Analisis Biaya dan Manfaat. Rineka Cipta, Jakarta.

Rangkuti, F., 2008. Business Plan. PT. Gramedia Pustaka Utama, Jakarta.

Sadjad, S., 1997. Membangun Industri Benih dalam Era Agribisnis Indonesia. PT. Gramedia Widiasarana Indonesia, Jakarta.

Soeharno, TS., SU., 2006. Teori Mikro Ekonomi. Andi, Yogyakarta.

Soeharto, 1997. Manajemen Proyek dari Konseptual dan Aplikasi. Rajawali Press, Jakarta.
Soekartawi, 1997. Agribisnis : Teori dan Aplikasinya. Raja Grafindo Persada, Jakarta.

Sudiyono, A., 2004. Pemasaran Pertanian. Universitas Muhamadiyah Malang, Malang.

Tenda, E, T., 1995. Pertumbuhan Bibit Kelapa Hybrid Genjah Salak X Beberapa Kelapa Dalam. Buletin Balitka 24 : 23-29.

Tumilaar, R., 2008. Produksi Kopra Turun Drastis, Petani Dihimbau Lakukan Peremajaan. Balai Pengkajian dan Pengembangan Informasi Wilayah VIII. Manado. Umar, H., 2003. Studi Kelayakan dalam Bisnis Jasa. Gramedia Pustaka Utama, Jakarta.

Umar, 2004. Wawasan Studi Kalayakan dan Evaluasi Proyek. PT. Bumi Aksara, Jakarta.

Winardi, 1996. Kamus Ekonomi (Inggris-Indonesia). Mandar Maju, Bandung.

Zubir, Z., 2006. Studi Kelayakan Usaha. Universitas Indonesia, Jakarta. 
Jurnal Untika Luwuk 2012 
Jurnal Untika Luwuk 2012 